\title{
Fiscal Policy and Default Risk in Emerging Markets*
}

\author{
Gabriel Cuadra ${ }^{\dagger} \quad$ Juan M. Sanchez Horacio Sapriza $^{\ddagger}$
}

February 2009

\begin{abstract}
Emerging market economies typically exhibit a procyclical fiscal policy: public expenditures rise (fall) in economic expansions (recessions), whereas tax rates rise (fall) in bad (good) times. Additionally, the business cycle of these economies is characterized by countercyclical default risk. In this paper we develop a quantitative dynamic stochastic small open economy model with incomplete markets, endogenous fiscal policy and sovereign default where public expenditures and tax rates are optimally procyclical. The model also accounts for the dynamics of other key macroeconomic variables in emerging economies.

JEL classification: E62, F34, F41.

Keywords: procyclical fiscal policy; sovereign default risk; endogenous borrowing constraints

The views expressed in this paper are those of the authors, and do not necessarily reflect those of the Federal Reserve Bank of Richmond or the Federal Reserve System.
\end{abstract}

${ }^{*}$ For useful comments we thank seminar participants at Banco de México, the 2006 North American Summer Meeting of the Econometric Society, the 2006 Society of Economic Dynamics Meeting, the 2006 LACEA Meeting and the 2006 Wegmans Conference at the University of Rochester. All remaining errors are our own.

${ }^{\dagger}$ Dirección General de Inv. Económica, Banco de México, México, email:gcuadra@banxico.org.mx.

${ }^{\ddagger}$ Federal Reserve Bank of Richmond, email: juan.m.sanchez@rich.frb.org.

$\S$ Board of Governors of the Federal Reserve System and Rutgers University, email:hsapriza@andromeda.rutgers.edu. 


\section{Introduction}

We study theoretically and quantitatively the links and cyclical behavior of fiscal variables, sovereign interest rate spreads and default risk in emerging market economies. In most middle and low income economies fiscal policy follows a procyclical behavior. A procyclical fiscal policy implies higher (lower) public spending and lower (higher) tax rates in good (bad) times. Developing economies also have more volatile business cycles and are more crisis prone than developed economies. ${ }^{1}$ In addition, these countries face countercyclical interest rate spreads in international credit markets: sovereign bond yields over US Treasuries increase (decrease) in expansions (recessions), making external credit more (less) expensive in bad (good) times, which is tightly linked to countercyclical default risk.

In this paper we rationalize these stylized facts on fiscal variables, interest rates and default risk in emerging market economies. For this purpose we develop a dynamic stochastic model of a small open economy with incomplete markets, endogenous fiscal policy and endogenous default risk.

The benchmark model features an economy with domestic households, a domestic government and foreign lenders. Households value private consumption, public spending and leisure. Public spending provides direct utility to the private sector, which prefers a smooth path of public spending over a volatile one. The government collects consumption taxes from households and borrows abroad to finance public expenditures.

\footnotetext{
${ }^{1}$ In the last decades emerging economies have experienced several debt crises, such as the Latin American debt crisis at the beginning of the 80s, the Mexican episode of 1994-1995 and later events such as the Russian crisis in 1998, Ecuador in 1999, Argentina in 2001 and Uruguay in 2003 among others. Sovereign debt crises usually take place in bad times, when output growth is low or even negative. See Uribe(2006) for a comparison of business cycle properties of developed and developing economies.
} 
Asset markets are incomplete since the only asset available to the government is a one period discount bond that pays the same in any state of nature next period provided the country does not default. Sovereign debt contracts are unenforceable and the government has the option to default on the outstanding debt every period. In case of default the economy experiences an output loss and is temporarily excluded from international credit markets. Foreign lenders charge a risk premium that accounts for the default risk they face. Hence, interest rate spreads reflect the sovereign default risk. Since the repayment of non-contingent loans is more costly in recessions, the incentives to default are higher in bad times. Thus, in recessions the government faces higher interest rate spreads due to higher default risk and finds it optimal to rely more heavily on taxation to finance public expenditures. On the other hand, in expansions the cost of international credit is lower so there is an increase in financing through borrowing, while taxes play a lesser role. Thus, tax rates are procyclical. Additionally, since the one period non-contingent bond is not a good instrument for consumption smoothing purposes, the government is not able to smooth public spending, so public expenditures are highly procyclical. Therefore, the government optimally implements a procyclical fiscal policy.

The private sector's participation in international credit markets has increased especially since the 1990s and it is well documented that in emerging countries private credit expands during consumption booms. ${ }^{2}$ The empirical literature also documents that the cost of public debt generally represents a floor for the cost of private borrowing. Durbin and Ng (2005) and Borensztein, Cowan and Valenzuela (2006) among others find that the credit-rating for government debt constitutes a ceiling for the credit ratings of the great majority of firms in the private sector. Some studies as early as Arrow and Lind

\footnotetext{
${ }^{2}$ IMF Financial Stability Report 2007, Figure 1.17. See also Copelman (2006).
} 
(1970) have argued that the public sector can handle risk better than the private sector because it can pool risk over a large number of projects and spread risk over a large number of taxpayers, making the real costs for government borrowing lower than for private borrowing. This is reflected in government bond rates that are generally lower than the market rate for private borrowing.

In order to take into account the effects of private foreign borrowing on the benchmark results, we develop a two period model where both the public and the private sector have access to foreign financing and may optimally default. The magnitude of the economic loss experienced by the country in a default event depends on whether it is the government, the private sector or both that decide not to fulfill the credit obligations. We find that fiscal policy is still procyclical and we also generate the procyclicality of private credit observed in the data.

In this vein, our paper studies the dynamic interaction between endogenous fiscal policy and sovereign debt financing, and their impact on the behavior of several key macroeconomic variables in emerging economies. Additionally, our work provides insight on the behavior of the private sector's participation in international financial markets. The dynamics of taxation, public expenditures, default, interest rate spreads and net exports in the model are thus derived as an equilibrium result from the interaction between the domestic government, the private sector of the small open economy and lenders in international credit markets.

In a quantitative analysis, we calibrate the model to the Mexican economy, a typical emerging market country. The results show that the calibrated model can mimic several empirical patterns for the macroeconomic variables previously described for emerging economies. 
The paper proceeds as follows: the link to the literature is provided in Section 2, the economic environment and the benchmark theoretical model are presented in Section 3 , and the equilibrium is defined in Section 4, the quantitative implications of the benchmark model are analyzed in Section 5. Section 6 discusses the robustness of the benchmark results to different assumptions regarding the economic environment. The impact of the private sector's access to international credit markets on the behavior of fiscal variables is studied in Section 7, where we develop and compute a finite horizon model where both the government and the private sector have access to foreign financing. The conclusions are presented in Section 8 . The algorithms for the benchmark model and the extensions are described in the Appendix in Section 9 .

\section{Link to the Literature}

The empirical regularities for emerging economies addressed in this paper are well documented in the literature. Gavin and Perotti (1997) (from now on GP) document that fiscal policy is procyclical in Latin America. Talvi and Vegh (2000) argue that far from being a particular feature of Latin American countries, a procyclical fiscal policy appears to be the norm among developing economies. They are also among the first to document that public spending is highly procyclical in the developing world and acyclical in the G-7 economies. More recently, Kaminsky, Reinhart and Vegh (2004) review the empirical evidence on the procyclicality of macroeconomic policy analyzing countries grouped by income level. They report that OECD countries seem to implement either countercyclical or acyclical fiscal policies while low and middle income countries appear to apply predominantly procyclical fiscal policies. Recently, Ilzetzki and Vegh (2008) analyze a quarterly dataset for 49 countries covering the period 1960-2006, they subject 
the data to several econometric tests and find evidence to support the idea that fiscal policy is procyclical in developing countries.

Additionally, GP observe that while governments in developed economies rely mostly on direct taxation for revenues, Latin American countries depend heavily on indirect taxes (including taxes on international trade), i.e., taxes on goods and services. ${ }^{3}$

Several episodes provide evidence strongly suggesting that tax rates are procyclical in developing economies. For instance, Talvi and Vegh (2005) document that during the economic boom in Argentina in 1991-1994 tax rates were reduced. When the economy fell into recession in 1995 they implemented a contractionary fiscal policy that involved tax rate increases. In that same year Mexico also experienced a severe recession and the value added tax was increased from 10 to 15 percent. In 1996 Argentina resumes a positive growth path and again adopts tax rate cuts (halved the $21 \%$ value-added tax on consumer and mortgage interest, etc.). Yet again in 2001 in the midst of a severe recession and increasingly tighter credit market conditions, the government imposed a "zero deficit" policy, which involved a fiscal package that once more included an increase in taxes, such as the gas tax. Uruguay's debt crisis of 2002-2003 provides yet another example of fiscal procyclicality. As observed by Vicente and Rial (2007), in the middle of the recession and capital flights the Uruguayan government dramatically increased taxes. In 2005, in the middle of an expansionary period, taxes in the country were reduced. Mailhos and Sosa (2000) show that tax rates for Uruguay have followed a procyclical pattern.

GP argue that inflation has had a close link with fiscal policy in Latin America.

\footnotetext{
${ }^{3}$ Indirect taxes account on average for almost $55 \%$ of total tax revenues in the region and show an upward trend, and international trade taxes account for $16 \%$.
} 
While they acknowledge that inflation may have been in part the endogenous result of financial crises associated with large fiscal imbalances, they point out that fiscal deficits in Latin American economies have been associated with subsequent increases in inflation, suggesting that inflation has acted much more like an instrument of fiscal policy in these countries compared to developed economies. In this context, they analyze the cyclical properties of the inflation tax in Latin America and find that it is low (high) in good (bad) times. In sharp contrast to the evidence for developing economies, Talvi and Vegh (2000) find that in advanced economies the inflation tax tends to increase during expansions and fall during recessions. In a study on the welfare effects of inflation, Erosa and Ventura (2001) find that the modeling of inflation makes it serve effectively as a regressive consumption tax. This reinforces the idea of the countercyclicality of tax rates and thus the procyclicality of fiscal policy in developing countries.

The documented procyclicality of fiscal policy in most developing countries contrasts with the normative fiscal policy prescriptions. Keynesian models imply that fiscal policy should be countercyclical: the government should reduce (increase) public expenditures and increase (reduce) tax rates in good (bad) times. In contrast, neoclassical models of fiscal policy inspired in Barro (1979) imply that fiscal policy should remain basically neutral over the business cycle. Therefore, if governments followed the Keynesian prescription, fiscal policy would be countercyclical. On the other hand, if they followed the prescription from tax smoothing models, fiscal policy would be acyclical.

What explains then the procyclicality of fiscal policy in most developing countries? A number of explanations have been advanced, including weak political institutions, incomplete markets and borrowing constraints.

Lane and Tornell (1999) argue that in economies without strong legal and political 
institutions a "voracity" effect may take place. In good times a windfall in fiscal revenues intensifies the struggle for public resources. Every interest group tries to get its share without completely internalizing the effect on general taxation. As a result, a more than proportional rise in public spending is observed. Talvi and Vegh (2005) develop a model that includes a political distortion, which increases the cost of running fiscal surpluses during economic expansions. In this model, the government cuts tax rates in good times in order to avoid spending pressures. Alesina and Tabellini (2006) explain the procyclicality of fiscal policy with a political agency model. Voters observe output accurately but not the rents appropriated by corrupt governments. In good times, voters demand more public goods or lower taxes as they anticipate that, otherwise, windfall revenues will be wasted by corrupt governments. However, the explanations based on political economy considerations are at odds with the fact that fiscal policy has also found to be procyclical during long dictatorships and very stable regimes. The large fiscal adjustments following the Latin American debt crisis in the early 1980s illustrate the point (also see for instance the empirical study on fiscal cyclicality for Uruguay by Mailhos and Sosa (2000)).

Riascos and Vegh (2003) develop a neoclassical model of fiscal policy in which public consumption provides direct utility to households. The government optimally chooses both the level of public consumption and the tax rate. With complete markets government consumption is acyclical. They also consider the case of incomplete markets, where the only asset available to the economy is risk-free debt. With incomplete markets the government is less able to smooth its consumption and the correlation between output and public consumption becomes positive. They suggest that the lack of complete markets in developing countries may be an important determinant of the cyclical 
properties of government spending in these economies. In their model, however, the government can commit to pay its debt, so it faces the same interest rate across states. Since the government always borrows at the international risk free rate, the model is not able to generate a negative correlation between output and tax rates.

Our model does not require a negligent behavior from the part of the government to explain the observed empirical regularities. That is, in the setup in this paper the government is fully rational, and aims to maximize the utility of the domestic households. Also, this paper does not need to resort to political distortions or changes in the preferences of the households regarding public spending during the cycle that are difficult to measure, as previous papers that have dealt with this question have done. Additionally, the model implications are quantitatively assessed using Mexican data for 1980-2007, thus suggesting the model as a plausible theory not only from a theoretical point but also from a quantitative perspective Finally, this model also advances the literature on sovereign debt and default risk by looking at the implications of fiscal policy on the behavior of the spreads and flows of public and private debt to emerging economies.

GP stress the role of borrowing constraints in explaining the procyclicality of fiscal policy in Latin American countries. They argue that these governments face a loss of access to external credit markets during bad times, which makes it extremely difficult to implement either a countercyclical or an acyclical fiscal policy, and they present some evidence that international credit constraints are more severe during recessions. Although these constraints cannot be observed directly, they infer their presence from the use of IMF emergency credit, which is usually provided when there are no other sources of financing. They find that the use of this credit is more frequent in bad macroeconomic times. However, GP only emphasize the importance of borrowing constraints without 
developing a model.

Aizenman, Gavin and Hausmann (2000) construct a two period model in which the government can either tax households or borrow from abroad to finance an exogenous amount of public goods. The government can default on its debt and a large recession forces it to its credit ceiling, resulting in a complete loss of market access, in which case the government is forced to increase taxes to finance its expenditures.

Our study considers a dynamic stochastic small open economy model with incomplete markets, endogenous fiscal policy and default risk and is thus related to the recent literature of quantitative models of sovereign debt. Following the seminal study on international lending and sovereign default by Eaton and Gersowitz (1981) and the more recent quantitative analysis on unsecured consumer default by Chatterjee et al. (2007), quantitative models on sovereign default by Aguiar and Gopinath (2006), Arellano (2008), Cuadra and Sapriza (2008), Hatchondo, Martinez and Sapriza (2008), Lizarazo (2006) and Yue (2007) among others, have analyzed different features of the dynamics of sovereign debt and default in emerging markets. However, these studies do not consider any fiscal policy implications.

Therefore, as far as we know our paper presents the first effort to explain the procyclical behavior of fiscal policy in developing countries within a quantitative model of endogenous sovereign debt and default in an incomplete markets framework. Additionally, the model helps to explain the procyclicality of fiscal policy based on the tightening of borrowing constraints in bad times through endogenous credit risk dynamics. One might interpret the tightening of borrowing constraints as a full cut off from international credit markets during recessions. Talvi and Vegh (2005) criticize this explanation arguing that developing countries do not always lose access to foreign borrowing during 
recessions. In our paper, although defaulting is more tempting in bad times, an adverse shock does not always induce the government to default on its foreign debt. The government only defaults when the recession is sufficiently large and the government is already highly indebted. When the default option is exercised, the country is temporarily excluded from international credit markets and public expenditures have to rely on taxes. When the government faces a negative shock and does not default, it has the option to borrow from abroad, though at a high interest rate. Since the cost of external credit increases in recessions, financing public expenditures with foreign debt becomes a relatively less attractive option. Thus, the probability of default and the associated risk premium in an incomplete markets setting are the major factors in explaining the procyclicality of fiscal policy.

Empirical studies have estimated these probabilities, finding that incentives to default are higher in recessions. ${ }^{4}$ The countercyclicality of interest rate spreads in the model is closely linked to the dynamics of the default probabilities perceived by the market. This is consistent with the empirical evidence from emerging markets from Neumeyer and Perri (2005) and Uribe and Yue (2006), who document that the cost of foreign credit is higher in recessions than in expansions, and with Cantor and Packer (1996) who find that sovereign credit ratings, which are valuations on the probability that a borrower will pay back its debts, strongly respond to the GDP growth rate.

\section{The Benchmark Model}

We consider a small open economy model with three agents: households, government and foreign lenders. Households have preferences over private consumption, public

\footnotetext{
${ }^{4}$ See Peter (2002) for a survey of econometric studies on the probability of sovereign default.
} 
spending and leisure. They work and consume, taking as given the actions of the government. Goods are produced using labor and the production function has constant returns to scale and is subject to technology shocks. The government cares about households and seeks to maximize their utility. It borrows from abroad, taxes households and finances public expenditures. The only asset traded in international credit markets is a one period non contingent bond that is available to the government, which is the only domestic agent that is able to borrow and lend. ${ }^{5}$ Debt contracts are not enforceable since the government has the option to default on them. When it defaults, it is temporarily excluded from credit markets and the economy suffers an output loss. Foreign lenders charge a premium to account for the probability of not being paid back by the government.

\subsection{Households}

There is a representative household with preferences given by the present value of the sum of instantaneous utility functions:

$$
E_{0} \sum_{t=0}^{\infty} \beta^{t} U\left(C_{t}, G_{t}, 1-l_{t}\right)
$$

The per period utility is concave, strictly increasing and twice differentiable. The discount factor is $\beta \in(0,1)$ and households derive utility from private consumption, public expenditures and leisure. Let $C_{t}$ represents private consumption, $G_{t}$ public spending and $l_{t}$ the amount of time allocated to produce goods. Output is produced using labor

\footnotetext{
${ }^{5}$ Most external debt in developing countries represents government debt. For example, in 1995 during the Mexican financial crisis, sovereign external debt accounted for almost $70 \%$ of the total stock of foreign debt in Mexico.
} 
services and the production technology is subject to productivity shocks.

$$
y_{t}=A_{t} F\left(l_{t}\right)
$$

where $A_{t}$ represents the productivity factor that is assumed to follow a Markov process, with $Q\left(A_{t+1} \mid A_{t}\right)$ denoting the Markov transition function for $A$, which has values defined over the set $\Upsilon$. Output can be divided between private and public consumption.

The government taxes private consumption ${ }^{6}$ and has two instruments to finance its expenditures: the proceeds from taxation and external borrowing. The representative household takes public expenditures and taxation as given and makes private consumption and labor decisions, subject to the following budget constraint:

$$
\left(1+T_{t}\right) C_{t}=A_{t} F\left(l_{t}\right)
$$

where $T$ is the tax rate on private consumption.

From households' first order conditions we get the following equation, describing optimal behavior of the private sector.

$$
\frac{U_{l}(C, G, 1-l)}{U_{c}(C, G, 1-l)}=\frac{A F_{l}(l)}{(1+T)}
$$

\subsection{Government}

The benevolent government maximizes the utility of the households in the economy and can borrow and lend in international credit markets. Financial markets are incomplete since the government can only save and indebt itself by selling and buying a non contingent one period bond. In order to finance its expenditures, the government can borrow from abroad and tax households through a consumption tax.

\footnotetext{
${ }^{6}$ As mentioned before, GP observe that Latin American countries depend heavily on non tax revenues and indirect taxes, i.e., taxes on goods and services.
} 
Each period, conditional on being in good credit standing the government chooses between honoring its outstanding foreign debt or defaulting on it. This decision comes from comparing the net benefits of the two options. Thus, the government compares the cost of temporary exclusion from credit markets given by the foregone benefits of consumption smoothing and the output loss in autarky, against the direct costs of repayment given by the short-run disutility of lowering current consumption to repay the non contingent loan.

The intertemporal problem of the government can be expressed in a recursive dynamic programming form. Conditional on having access to credit markets, the government has to decide whether to default or not; if default is not optimal then it has to decide how much borrowing or saving to do and it has to make two fiscal policy decisions, i.e., the amount of public expenditures and the level of the consumption tax. If default is optimal then the government only has to decide its fiscal policy. All these decisions are made given the productivity shock and the amount of outstanding foreign assets it has. Thus, the state variables are the productivity factor $A$, the level of foreign assets $B$ and the credit situation of the country, $d$, where $d=1$ if the economy has access to credit markets and 0 if the country is in financial autarky.

The value function when the government has access to international markets and begins the period with an amount of assets $B$ and shock $A$ is given by $V_{0}(B, A)$. The government has to decide between honoring its debt and defaulting on it, by comparing the value associated with paying back and remaining in the credit market $V^{c}(B, A)$, with the value associated with defaulting and going to temporary autarky $V^{d}(A)$. The problem can be expressed in the following way:

$$
V_{0}(B, A)=\max \left\{V^{c}(B, A), V^{d}(A)\right\}
$$


and the optimal default decision of the government is characterized by

$$
D(B, A)=\left\{\begin{array}{cl}
1 & \text { if } V^{c}(B, A)>V^{d}(A) \\
0 & \text { otherwise }
\end{array}\right.
$$

The default policies determine a repayment set $\Gamma(B)$; this is defined as the set of values of the productivity shock such that repayment is the optimal decision given the level of foreign assets $B$,

$$
\Gamma(B)=\{A \in \Upsilon: D(B, A)=1\}
$$

and a default set $\digamma(B)$ defined as the set of values of the productivity shock such that default is optimal given asset holding level $B$,

$$
\digamma(B)=\{A \in \Upsilon: D(B, A)=0\}
$$

If the government does not default, it can issue new debt and finance its expenditures according to the following restriction:

$$
G=T C+B-q\left(B^{\prime}, A\right) B^{\prime}
$$

where $q\left(B^{\prime}, A\right)$ is the price of the bond that pays one unit of consumption goods the following period if the government does not default on its debt. When the government borrows, it sells bonds to foreign lenders, so it receives $q\left(B^{\prime}, A\right) B^{\prime}$ units of consumption goods from foreign creditors on the current period and promises to pay $B^{\prime}$ units next period conditional on not defaulting.

In a similar way, when the government lends, it buys bonds from foreign creditors. If the government purchases a bond of value $B^{\prime}$, today it lends $q\left(B^{\prime}, A\right) B^{\prime}$ units of the good to foreign creditors and it will receive $B^{\prime}$ units the following period. If foreign creditors borrow from the domestic government it is assumed that they always pay back, only the 
domestic government cannot commit to repay its debt. Hence, the bond price reflects the probability of default, which depends on $B^{\prime}$ and $A$.

When the government has access to credit markets it chooses the tax rate, public expenditures and foreign assets in order to maximize households' utility, taking into account how the private sector will respond to these policies. Formally, the government maximizes utility subject to the households' budget constraint and the private sector's first order conditions, as well as its own budget constraint.

Thus, the problem of the government when it has access to credit markets is:

$$
\begin{aligned}
V^{c}(B, A)= & \max _{T, G, B^{\prime}}\left\{U\left(C^{*}, G, 1-l^{*}\right)+\beta \sum_{A^{\prime}} V_{0}\left(B^{\prime}, A^{\prime}\right) Q\left(A^{\prime} / A\right)\right\} \\
& \text { s.t. } \\
G= & T C^{*}+B-q\left(B^{\prime}, A\right) B^{\prime} \\
A F\left(l^{*}\right)= & (1+T) C^{*} \\
\frac{A F_{l}\left(l^{*}\right)}{(1+T)}= & \frac{U_{l}\left(C^{*}, G, 1-l^{*}\right)}{U_{c}\left(C^{*}, G, 1-l^{*}\right)}
\end{aligned}
$$

where $C^{*}$ and $l^{*}$ represent the optimal choice of private consumption and labor effort made by households, given the government's policies (i.e., $C^{*}$ and $l^{*}$ solve the households' first order conditions and budget constraint, given the policies implemented by the government: $T, G$, and $\left.B^{\prime}\right)$.

When the government defaults on its debt the country is temporarily excluded from international credit markets. In addition, the economy suffers an output loss, ${ }^{7}$ with the same amount of labor services households produce less goods. The productivity factor

\footnotetext{
${ }^{7}$ The assumption that default reduces output can be rationalized by the fact that after a default episode there is a disruption in foreign trade, Rose (2005), which induces an output loss. See also Arteta and Hale (2006) and Dooley (2000).
} 
in autarky is represented by $h(A)$. The problem is:

$$
\begin{aligned}
V^{d}(A)= & \max _{T_{d}, G_{d}}\left\{U\left(C_{d}^{*}, G_{d}, 1-l_{d}^{*}\right)+\beta \sum_{A^{\prime}}\left[\mu V_{0}\left(0, A^{\prime}\right)+(1-\mu) V^{d}\left(A^{\prime}\right)\right] Q\left(A^{\prime} / A\right)\right\} \\
& \text { s.t. } \\
G_{d}= & T_{d} C_{d}^{*} \\
h(A) F\left(l_{d}^{*}\right)= & \left(1+T_{d}\right) C_{d}^{*} \\
\frac{h(A) F_{l}\left(l_{d}^{*}\right)}{\left(1+T_{d}\right)}= & \frac{U_{l}\left(C_{d}^{*}, G_{d}, 1-l_{d}^{*}\right)}{U_{c}\left(C_{d}^{*}, G_{d}, 1-l_{d}^{*}\right)}
\end{aligned}
$$

$C_{d}^{*}$, and $l_{d}^{*}$ represents the optimal consumption and labor decisions when the country is in autarky. The tax on consumption is the only instrument to finance public expenditures.

The economy is excluded from credit markets in the current period but in the next one the country may regain access to external markets with an exogenous probability $\mu$. When the economy returns to financial markets, it does so with no debt burden, $B=0$. In this case the continuation value will be $V_{0}\left(0, A^{\prime}\right)$. On the other hand, with a probability $1-\mu$ the country will stay in autarky. In such a case, the continuation value will be $V^{d}\left(A^{\prime}\right)$.

\subsection{Foreign Lenders}

There is a large number of identical, infinitely lived foreign creditors. Each lender can borrow or lend at the risk free rate $r_{f}$ and participates in a perfectly competitive market to lend to the small open economy.

Lenders are risk neutral and maximize expected profits, which are given by the following equation

$$
\Phi=-q B^{\prime}+\frac{\lambda\left(B^{\prime}, A\right)}{1+r_{f}} 0+\frac{\left(1-\lambda\left(B^{\prime}, A\right)\right)}{1+r_{f}} B^{\prime}
$$


The first term of the equation above shows that when creditors lend to the government in the current period, they buy the discount bond issued by the domestic government at a price $q$. Next period the lenders may receive the face value of the bond depending on whether the government defaults or not. When it defaults, creditors get 0 units of the consumption good, where $\lambda\left(B^{\prime}, A\right)$ is the endogenous probability that the government defaults on its sovereign debt. Therefore, with probability $1-\lambda\left(B^{\prime}, A\right)$ lenders will be paid back an amount $B^{\prime}$.

Since there is perfect competition in the credit market, a zero profit condition for the foreign creditor is satisfied. The bond price is then ${ }^{8}$ :

$$
q\left(B^{\prime}, A\right)=\frac{\left(1-\lambda\left(B^{\prime}, A\right)\right)}{1+r_{f}}
$$

Thus, the equilibrium bond price $q\left(B^{\prime}, A\right)$ reflects the probability of default of the government, $\lambda\left(B^{\prime}, A\right)$, which results from

$$
\lambda\left(B^{\prime}, A\right)=\sum_{A^{\prime} \in \digamma\left(B^{\prime}\right)} Q\left(A^{\prime} / A\right)
$$

so that the default probability is zero when $\digamma\left(B^{\prime}\right)=\varnothing$ and it is one when $\digamma\left(B^{\prime}\right)=\Upsilon$.

\section{Equilibrium}

\subsection{Definition}

In equilibrium households choose optimal private consumption and labor effort given government policies and the government determines its optimal default policy and asset holding policy as well as its optimal fiscal policy subject to the private sector optimizing

\footnotetext{
${ }^{8}$ Alternatively, we could assume that foreign lenders have access to two instruments: a risky bond and a risk free bond. Since creditors are risk neutral, they are willing to buy the risky asset as long as its expected return equals the return of the risk free asset: $(1-\lambda)(1+R)=1+r_{f}$, with $q=\frac{1}{(1+R)}=\frac{(1-\lambda)}{1+r_{f}}$.
} 
and foreign lenders optimizing by satisfying their zero profit condition from the debt contract.

Definition 4.1. A recursive equilibrium for this small open economy is characterized by

1. A set of value functions $V_{0}, V^{c}$ and $V^{d}$ for the government,

2. A set of policy functions for household's consumption $C^{*}, C_{d}^{*}$ and household's labor supply $l^{*}, l_{d}^{*}$,

3. Policy functions for government's default decision $D$, optimal asset holdings $B^{\prime}$, optimal government expenditures $G, G_{d}$ and optimal tax rates $T, T_{d}$,

4. A bond price function $q$,

such that

1. Given the government policies and the bond price function, the household policies for consumption and labor solve the household's problem,

2. Given the bond price function $q$ and the optimal policies for households, the government's value functions $V_{0}, V^{c}$ and $V^{d}$ and its policy functions $D, B^{\prime}, G$ and $T$ solve (3.3), (3.8) and (3.9):

3. The equilibrium bond price $q\left(B^{\prime}, s\right)$ is such that international lenders get zero expected profits, (3.10). 


\subsection{First Order Conditions from Government's Problem}

The first order condition for the tax rate simplifies to:

$$
U_{c}(C, G, 1-l) \frac{A F\left(l^{*}\right)}{(1+T)^{2}}=U_{g}(C, G, 1-l)\left[\frac{A F\left(l^{*}\right)}{(1+T)^{2}}+\frac{T A F_{l}\left(l^{*}\right)}{(1+T)} \frac{\partial l}{\partial T}\right]
$$

This condition can be interpreted in terms of marginal benefits and marginal costs of changing the tax rate. In terms of effects on today's utility, a marginal increase in the tax rate affects private consumption, public spending and labor effort. The government increases taxes and reduces the consumption of private goods by $\frac{A F\left(l^{*}\right)}{(1+T)^{2}}$ units, which reduces today's welfare. On the other hand, the government increments public spending by $\frac{A F\left(l^{*}\right)}{(1+T)^{2}}+\frac{T A F_{l}\left(l^{*}\right)}{(1+T)} \frac{\partial l}{\partial T}$ units, increasing household's welfare. The first term in this expression corresponds to the resources reallocated from private consumption to public consumption. However, if households react working less hours when the government implements a higher tax rate, then the amount of resources that can be assigned to public expenditures would be reduced. This effect corresponds to the second term.

The Euler equation for the government is obtained from the first order condition of its dynamic optimization problem and the envelope theorem:

$$
U_{g}(C, G, 1-l)\left[q+B^{\prime} \frac{\partial q}{\partial B^{\prime}}-\frac{T A F_{l}\left(l^{*}\right)}{(1+T)} \frac{\partial l}{\partial B^{\prime}}\right]=\beta \sum_{A^{\prime} \in \Gamma(B)} U_{g}\left(C^{\prime}, G^{\prime}, 1-l^{\prime}\right) Q\left(A^{\prime} / A\right)
$$

The Euler equation is interpreted in terms of marginal benefits and marginal costs of additional lending or borrowing. We consider the case where the government is a net debtor. The marginal benefits and costs can be described as follows:

In terms of effects on current welfare, for each unit of additional borrowing the government could increase the level of public spending by $q+B^{\prime} \frac{\partial q}{\partial B^{\prime}}-\frac{T A F_{l}\left(l^{*}\right)}{(1+T)} \frac{\partial l}{\partial B^{\prime}}$ units. Additional borrowing would affect the amount of resources available to finance public 
spending. Since the government is borrowing more it could afford a higher level of public expenditures: in principle it could increase public consumption in $q$ units, but at the same time, if the government is already indebted, additional borrowing would increase the interest rate that it faces in international markets because default probabilities are increasing in foreign debt. The decreasing bond price implies that the government does not obtain as many resources from selling bonds as it would under a constant bond price. The term $B^{\prime} \frac{\partial q}{\partial B^{\prime}}$ reflects that when evaluating the benefits and costs of additional external borrowing, the government takes into account the fact that issuing more bonds would decrease the price.

The government's borrowing can affect the idiosyncratic bond price that it faces: if the government issues additional bonds, default probabilities will be higher and foreign creditors will demand a lower price, otherwise they will not buy the bonds. In addition, extra borrowing affects the labor supply and hence the level of output. If households responded by supplying less labor, for a given tax rate the proceeds from taxing households would be lower. Thus, the resources available for financing public consumption would be reduced. This effect depends on the sign of $\frac{\partial l}{\partial B^{\prime}}$ and corresponds to the term $\frac{T A F_{l}\left(l^{*}\right)}{(1+T)} \frac{\partial l}{\partial B^{\prime}}$. Increasing $B^{\prime}$ can only be optimal if it allows the government to increase $G$, i.e. if $q+B^{\prime} \frac{\partial q}{\partial B^{\prime}}-\frac{T A F_{l}\left(l^{*}\right)}{(1+T)} \frac{\partial l}{\partial B^{\prime}}>0$. In this case the extra resources are used to rise public spending, increasing current utility. Next period, the government would have to repay its debt, which reduces future government consumption. However, it only pays back when it is optimal, so households only end up enjoying less public goods in those states where the government does not default and honors its debt. 


\section{Quantitative Analysis}

The benchmark model is solved numerically and the parameters are based on existing data. Given the availability of time series of data, Mexico is used as a benchmark and our period of study is 1980-2007. Many of the business cycles features observed in Mexico are shared by other emerging market economies.

\subsection{Data}

The data are seasonally adjusted quarterly real series obtained from Banco de Mexico. Output, private consumption and public consumption are in logs and the trade balance is presented as a percentage of GDP. An effective tax rate was computed for the consumption tax using the methodology of Mendoza, Razin and Tesar (1994). The interest rate spreads corresponds to the EMBI for 1994-2007. All other series are from 1980 to 2007. All series are filtered with the Hodrick-Prescott filter.

\subsection{Calibration}

The calibration involves choosing the functional forms and the parameter values. The parameters are chosen based on existing empirical work on emerging markets, if available. Otherwise they are set to mimic empirical regularities of emerging markets.

The per period utility function of households is specified as:

$$
U(C, G, 1-l)=\pi\left(\frac{G^{1-\sigma}}{1-\sigma}\right)+(1-\pi)\left(\frac{\left(C-\frac{l^{1+\Psi}}{1+\Psi}\right)^{1-\sigma}}{1-\sigma}\right) .
$$

The first term of the function has the GHH (1988) specification, which has the property that the marginal rate of substitution between private consumption and labor is independent of consumption. Therefore, the labor supply does not depend on the level of 
consumption and has elasticity $\frac{1}{\Psi}$. In addition, public expenditure $G$ and private sector variables, i.e. $C$ and $l$, are separable.

There is a linear production technology, where labor is the input:

$$
A F(l)=A l .
$$

Given these preferences and technology, and combining the first order condition of household's problem and her budget constraint, the optimal labor supply policy of households is

$$
l^{*}=\left[\frac{A}{1+T}\right]^{\frac{1}{\Psi}} .
$$

The household's labor supply depends on the productivity factor, the tax rate and the parameter $\Psi$ of the per period utility. A higher tax on consumption reduces the optimal level of labor, whereas a higher productivity shock increases it.

The productivity shock is assumed to follow an $\mathrm{AR}(1)$ process

$$
\ln \left(A_{t}\right)=\rho \ln \left(A_{t-1}\right)+\varepsilon_{t}
$$

with $E(\varepsilon)=0$ and $E\left(\varepsilon^{2}\right)=\sigma_{\varepsilon}^{2}$.

There is an output loss in autarky, households produce less goods with the same amount of labor services. Arteta and Hale (2006), Rose (2005) and Dooley (2000) among others, provide a rationale for the loss of output when countries face debt crises. The productivity factor in autarky $h(A)$ is specified following Arellano (2008). Thus, it is assumed that default entails some direct output cost of the following form:

$$
h(A)=\left\{\begin{array}{cc}
\phi E(A) & \text { if } A>\phi E(A) \\
A & \text { if } A \leq \phi E(A)
\end{array}\right.
$$

With $\phi \in(0,1)$. 
The parameters for the model are shown in Table 1. Some of the parameter values that are used are standard for business cycles models in emerging markets. The parameter $\sigma$, the coefficient of relative risk aversion, is set equal to 2, a standard value (see Aguiar and Gopinath 2006). The parameter $\Psi$ is set to 0.455 following Mendoza (1991). This parameter determines the labor supply elasticity $\frac{1}{\Psi}$.

The discount factor $\beta$ is set at 0.97 . This value helps to approximately match the public consumption volatility close to $3 \%$ for the Mexican economy during our sample period. One weakness of quantitative models of sovereign default is that they require a high level of impatience to generate default in equilibrium. By considering an asymmetric output penalty we can use a more reasonable value (see Arellano (2008)).

The parameter $\mu$ reflects the exogenous probability of reentering international capital markets after default and is set equal to 0.1 . This value implies that a defaulting country will return to financial markets in about 10 quarters after defaulting on its foreign debt. This is in line with the exclusion period observed in the data by Gelos, Sahay and Sandleris (2003), who calculated the average number of years that a country was excluded from international financial markets to be close to 3 years for countries that defaulted on their foreign debt during the period 1980 - 1999.

The parameter of the cost of default $\phi$, is calibrated to match the external debt service to GDP ratio, $4.5 \%$ for Mexico. The risk free interest rate is set equal to $1 \%$, which corresponds to the US annual interest rate. The parameters of the stochastic process for the productivity factor are set to match the cyclical properties of GDP in Mexico: the autocorrelation and standard deviation of the Mexican output. The process of output is approximated by a discrete first order Markov chain with 25 values using the procedure in Tauchen (1986). 
Given the values of the parameters and the preferences, which are specified in equation (5.1), a value of $\pi$ equal to 0.30 allows the model to generate a public spending - private consumption ratio equal to $16 \%$, which corresponds to the mean value for Mexico during the period of study.

\subsection{Results}

This section presents the simulation results and the statistical properties of the benchmark model. The second column of Table 2 shows the business cycle moments of several macroeconomic variables for the simulated small open economy. Business cycles statistics are average values over 1000 simulations of 50 realizations each, drawn from a stationary distribution. The simulated series are logged and filtered.

The model economy is able to match several stylized facts in emerging markets: Incentives to default are higher for highly indebted countries, default risk and interest rates are countercyclical, public and private consumption are positively correlated with output, tax rates increase (fall) in recessions (expansions), the trade balance is negatively correlated with output and the volatility of consumption is higher than the volatility of output. Additionally, in good times the country borrows more at lower interest rates.

Figure 1 plots the discount bond price schedule as a function of assets for two values of the productivity shock. As the figure shows, given a shock, the bond price is an increasing function of foreign assets. For small levels of foreign debt, the government always pays back its debt, so it borrows from international markets at the world risk free interest rate. In this range of debt, the bond price is simply the inverse of the gross risk free rate. However, as the foreign debt increases, at a certain level the bond price starts to decrease because the incentives to default are stronger for highly indebted 
governments. At a sufficiently large debt level the government always defaults regardless of the output realization. At that point the probability of default is one so the bond price is zero.

The bond price schedules also illustrate that for all levels of debt, the bond price is lower (higher interest rate) when the economy is hit by an adverse output realization. This result derives from the presence of incomplete asset markets in the model. This market structure makes defaulting on foreign debt more attractive in bad times when output is low since the repayment of non contingent loans is more costly in recessions. Since productivity shocks are persistent, lending resources to the government in times of low output involves a higher default risk. Thus, risk neutral lenders are willing to lend resources to the government by charging a higher interest rate. The simulated sequence plotted in Figure 2 shows how the interest rate spread increases as output contracts in the economy.

The consumption tax and output are negatively correlated, implying that in bad times when the government has limited access to international credit markets it taxes more heavily on consumption in order to get resources to finance its expenditures. In good times foreign credit is cheaper, the government finances its expenditures mainly through external borrowing. Thus, the lack of government commitment to repay its debt induces a procyclical tax rate. Figure 3 shows the dynamics of GDP and tax rates from a simulation of the model economy.

A key feature of the model to understand why the government relies more on taxes in recessions is the asset structure of the model that makes default more tempting in recessions. Hence, if the government defaults then it is the case that an adverse shock has hit the economy. Therefore, in the middle of a recession, a highly indebted govern- 
ment losses access to credit markets and it has to finance its expenditures with taxes. However, if the productivity shock is low but the government is not highly indebted then it might find optimal to pay back and remain in good standing in international markets. At the same time, since the productivity shock is persistent a low realization today implies a higher probability of experiencing a bad shock tomorrow. Therefore, a lower productivity shock today increases the default risk for a given amount of external borrowing. Thus, in bad times, even if the government does not default it faces higher interest rates, making the use of external debt to finance public expenditures a relatively less attractive option. Under such circumstances, the government finds it optimal to rely more heavily on taxes financing. Figure 4 presents the tax policy function $T(B, A)$ as a function of $B$ for two values of the productivity shock. When the amount of foreign debt is low and the government always pays back its debt, the country faces the risk free interest rate and the optimal tax rate increases with $A$. However, when the foreign debt is high enough such that it carries a positive risk premium, the optimal tax rate decreases when a positive productivity shock occurs.

Similarly, public spending is procyclical because it is valued by households and markets are incomplete. Since default is more attractive in bad times, the bond price is low (high) in recessions (expansions). Thus, the asset structure in the model and the countercyclicality of interest rates substantially reduce the ability of the government to smooth consumption and make both public and private consumption highly positively correlated with output. These results highlight the importance of the countercyclicality of the sovereign spreads in driving the procyclicality of tax rates and public expenditures.

Finally, the calibrated economy experiences a countercyclical trade balance and procyclical borrowing. The availability of external credit and the interest rate vary with 
the business cycle: foreign lenders respond to an improvement in the domestic macroeconomic conditions by demanding a lower risk premium, which entices the government to dissave. Additionally, since productivity shocks are persistent, a positive shock today increases the probability of a good shock next period and the increased likelihood of a higher future income also induces the government to borrow more. Figure 5 shows the borrowing policy function $B^{\prime}(B, A)$ conditional on not defaulting, as a function of $B$ for two values of the productivity shock. When the country is highly indebted, the government borrows more in booms than in recessions. When debt is small the country experiences no default risk and therefore borrows at the international risk free rate even for low income realizations. Therefore, in this region the economy borrows more in recessions and less in expansions as in standard insurance models with borrowing constraints a la Hugget (1993). Finally, the higher volatility of consumption than output derives from the procyclicality of borrowing. In low income states, borrowing is relatively expensive so the government is constrained and tax rates are raised, thus consumption decreases similarly to output and the trade balance tends to be positive. In expansions, the cheap foreign credit stimulates borrowing and low tax rates, which induce consumption to raise above income and the trade balance to become negative.

\section{Discussion}

In this section we conduct a robustness check of the benchmark results. In this sense, we study the implications of different features of the benchmark model on the dynamics of fiscal and financial variables. We first analyze the role of default in the model. Secondly, we look at different preference specifications and parameters and then we consider a labor tax instead of a consumption tax. Finally, we consider a model with defaultable 
public and private foreign debt, where we also analyze the role of commitment on the dynamics of sovereign debt and fiscal policy.

One of the distinguishing features of the study is the presence of default risk, so we first consider the model dynamics in the absence of it. Table 3 compares the benchmark results with and without default. In the model without default, the government faces a constant interest rate in international markets, which is equal to the risk free interest rate. ${ }^{9}$ Thus, interest rates do not fluctuate countercyclically anymore. While public expenditures are still procyclical because they are valued by households and markets are still incomplete, the tax rate ceases to fluctuate procyclically. Therefore, in bad times the economy has now stronger incentives to finance both private and public consumption by increasing its borrowing instead of tax rates. Now, the optimal cyclical pattern for borrowing and tax rates, imply a slightly positive correlation of these variables with GDP. However, as discussed earlier, such dynamics are counterfactual.

We also consider CES preferences in private consumption and public spending in an endowment setting in order to assess the effect of varying degrees of complementarity and substitutability between these two choice variables on the model dynamics.

$$
\left[\delta G^{-\varsigma}+(1-\delta) C^{-\varsigma}\right]^{-\frac{1}{\varsigma}}
$$

According to this specification, the value of the preference parameter $\varsigma$ can take values equal or larger than -1 , where $\varsigma=0$ indicates a Cobb Douglas functional form. A value of $\varsigma$ toward -1 corresponds to closer to perfect substitutes and a value of $\varsigma$ toward infinity represents closer to perfect complements. The results for the different

\footnotetext{
${ }^{9}$ The model without default has an adjustment cost for debt specified as $\varphi / 2\left(B^{\prime}-\bar{B}\right)^{2}$ to have the steady state well defined. The values for $\varphi, \bar{B}$ are set to match the debt service and volatility of the trade balance of the benchmark model (see Uribe and Schmitt-Grohe (2003)).
} 
specifications appear on Table 4. As the numbers in the table show, the qualitative results stand and overall results do not change significantly. As private consumption and public spending become less substitutes and more complements, the ratio G/C tends to 1 . If they are perfect complements, one unit of $\mathrm{G}$ is consumed together with one unit of $\mathrm{C}$, and the tax volatility increases but the interest rate spreads, the correlation of the interest rate spreads with gdp, debt/gdp, etc., do not change. As the goods become more complements the government tends to implement a larger tax to redistribute the resources according to the optimal allocation between C and G. Thus, only the tax rate and the $\mathrm{G} / \mathrm{C}$ ratio are affected. For instance, with a value of $\varsigma=-0.5$ (close substitutes) the government implements a relatively small tax to transfer a small amount of resources towards G compared to the complements case.

We also consider a labor tax instead of a consumption tax. Table 3 compares the benchmark model with a consumption tax and a model with a labor tax. As we can see, the results are quite similar Combining the first order condition of household's problem and her budget constraint, we get the optimal labor supply policy when the government implements a labor tax:

$$
l^{*}=\left[\left(1-T_{l}\right) A\right]^{\frac{1}{\Psi}} .
$$

The optimal household's labor decision depends on the productivity factor, the tax rate and the parameter $\Psi$ of the per period utility. A higher labor tax reduces the optimal level of labor, whereas a higher productivity shock increases it. Thus, the effects are similar to those of the consumption tax and the optimal fiscal policy remains procyclical. 


\section{The Model with private foreign borrowing}

The assumption that households cannot borrow directly from credit markets is in conflict with the increased participation of the private sector's debt in the overall bond issuance by emerging markets documented by the IMF (IMF Financial Stability Report (2007), Copelman (1996)). At the same time, the aggregate figures on private foreign borrowing conceal a significant cross country heterogeneity: while private foreign borrowing in countries like Estonia or Thailand is significant relative to public foreign borrowing, for a large number of developing countries it is almost exclusively the government that has access to international credit markets. This gives official borrowing a key role in the consumption smoothing of a large fraction of households in these economies (CEPAL (2008)). Lahiri, Singh and Vegh (2007) observe that in general, access to asset markets is limited to a fraction of the population, and even in the US the degree of segmentation in asset markets is remarkably high. For example, they point out that as of 1989, almost $60 \%$ of US households did not hold any interest bearing assets (defined as money market accounts, certificates of deposit, bonds, mutual funds, and equities) and $25 \%$ did not even have a checking account. They thus argue that this lack of household access to asset markets is likely to be much more severe in developing countries, where financial markets are much less developed. Claessens (2006) also documents that even in the US, still by 2001 about $10 \%$ of households did not hold any financial account. On the other hand, he shows that in developing countries the average usage of a bank account is only 26\%. Reinhart, Rogoff and Savastano (2003) document that historically, private foreign borrowing accounts for less than $10 \%$ of total foreign borrowing in more than $2 / 3$ of 
developing countries. ${ }^{10}$ Table 5 summarizes their finding.

Within the model, the lack of private foreign borrowing prevents households from adjusting their private consumption, thus potentialy overstating the role of public borrowing. To assess the robustness of our results to this assumption and see the mechanisms at play we consider a two-period endowment economy in which the private sector can also borrow abroad and choose to default. The magnitude of the economic loss experienced by the country in a default event thus depends on whether it is the government, the private sector or both that decide not to fulfill the credit obligations. The modeling captures the concept of "sovereign credit ceiling" observed in the data, i.e., the interest rate spread at which the government borrows in developing countries tends to set a lower bound for the spread paid by the private sector. This stylized fact is analyzed in numerous empirical studies such as Durbin and $\mathrm{Ng}$ (2005), Borensztein, Cowan and Valenzuela (2007) and Peter and Grandes (2005) among others.

\subsection{Results}

The government does not have commitment to long-run plans and chooses taxes $(\tau)$, debt $(B)$ and default $(D)$ before the private sector decides on debt $(b)$, and default $(d)$. Thus, each period, the private sector maximizes lifetime utility given the government's policy. Likewise, the government chooses the fiscal policy to maximize lifetime utility given the private sector's reactions to its actions. This type of problem is very suitable to be solved by backward induction. Therefore, we first present the last period problem.

\footnotetext{
${ }^{10}$ In order to gauge the importance of private foreign borrowing in these economies they look at the share of private sector external borrowing out of total external borrowing. They divide developing countries in two groups: those where private sector debt accounts for at least 10 percent of total external debt, and those where the share is below 10 percent.
} 
Notice that income $\widetilde{y}(y, d, D)$ depends on the output realization $y$ and the indicator function that shows whether the private $(d)$ and public $(D)$ sectors defaulted $(1)$ or not $(0) \cdot{ }^{11}$

Suppose in the second period the government decided to payback its debt and to set taxes at $\tau$. Then, the private sector's problem is

$$
\begin{aligned}
U_{n d}^{2}(b, B, y, \tau)= & \max _{d \in\{0,1\}} u(c, c \tau+B) \\
& \text { subject to } \\
\widetilde{y}(y, d, D)= & -I_{(d=0)} b+c(1+\tau),(\text { HH's bc). }
\end{aligned}
$$

Likewise, suppose in the second period the government decided to default on its debt and to set taxes at $\tau$. Then, the private sector's problem is

$$
\begin{aligned}
U_{d}^{2}(b, y, \tau)= & \max _{d \in\{0,1\}} u(c, c \tau) \\
& \text { subject to } \\
\widetilde{y}(y, d, D)= & -I_{(d=0)} b+c(1+\tau) .
\end{aligned}
$$

Thus, the government's problem is then to choose taxes and default to maximize lifetime utility taking the private sector's reaction to its policy as given; i.e.,

$$
V^{2}(b, B, y)=\max _{\tau, D \in\{0,1\}}\left\{D * U_{d}^{2}(b, y, \tau)+(1-D) * U_{n d}^{2}(b, B, y, \tau)\right\}
$$

Notice that $V^{2}(b, B, y)$ is useful because this is the function used in the first period to compute the effect of borrowing on the utility in the second period. Now we describe the first period problem. Let $q_{p}(b, B, y)$ and $q_{g}(b, B, y)$ be the price of the private sector's

\footnotetext{
${ }^{11}$ We will look at the problem of one (representative) agent in the private sector. Thus, we assume that all agents in the economy have the same $y$ and they are allowed to trade only with foreign lenders (i.e., we rule out interactions among individuals in the private sector).
} 
and government's debt, respectively. These prices are determined by the (expected) zero profit conditions and depend on the amount borrowed by the private sector, $b$, the government, $B$, and the first period income, $y$. Those prices are taken as given by the government and the private sector.

If in the first period the government decided to payback its debt, set taxes at $\tau$, and accumulate $B^{\prime}$ for the next period, then the private sector's problem is

$$
\begin{aligned}
U_{n d}^{1}\left(b, B, y, \tau, B^{\prime}\right)= & \max _{\substack{d \in\{0,1\}, b^{\prime}\\
}} u\left(c, c \tau-I_{(d=0)} q_{g}(b, B, y) B^{\prime}+B\right)+\beta E_{y^{\prime}} V^{2}\left(I_{(d=0)} b^{\prime}, I_{(d=0)} B^{\prime}, y\right) \\
& \text { subject to } \\
\widetilde{y}(y, d, D)= & I_{(d=0)}\left[q_{p}(b, B, y) b^{\prime}-b\right]+c(1+\tau), \\
& \text { and given } q_{p}(b, B, y), q_{g}(b, B, y) .
\end{aligned}
$$

Thus, if the private sector defaults, then it is excluded of credit markets. Additionally, the term $I_{(d=0)} q_{g}(b, B, y) B^{\prime}$ indicates that in case of default in the private sector, the government is also excluded from credit markets.

If the government decided to default on its debt and to set taxes at $\tau$. then, the private sector's problem is

$$
\begin{aligned}
U_{d}^{1}(b, y, \tau)= & \max _{d \in\{0,1\}} u(c, c \tau)+\beta E_{y^{\prime}} V^{2}(0,0, y) \\
& \text { subject to } \\
\widetilde{y}(y, d, D)= & -b I_{(d=0)}+c(1+\tau) .
\end{aligned}
$$

Therefore, if the government defaults, credit markets are closed for both the government and the private sector. The government problem is then

$$
V^{1}\left(b_{0}, B_{0}, y\right)=\max _{\tau, D \in\{0,1\}, B^{\prime}}\left\{D * U_{d}^{1}(b, y, \tau)+(1-D) * U_{n d}^{1}\left(b, B, y, \tau, B^{\prime}\right)\right\}
$$


The policy functions used in the simulations below are those that solve the first period problem. In particular, given the initial state $\left(b_{0}, B_{0}, y\right)$, we have the policy functions for the government, $\tau\left(b_{0}, B_{0}, y\right), B^{\prime}\left(b_{0}, B_{0}, y\right), D\left(b_{0}, B_{0}, y\right)$, and the private sector, $b^{\prime}\left(b_{0}, B_{0}, y\right)$, and $d\left(b_{0}, B_{0}, y\right) .{ }^{12}$ Notice that using the private sector's and the government's budget constraints, we also have $C\left(b_{0}, B_{0}, y\right)$ and $G\left(b_{0}, B_{0}, y\right)$. Thus, we are now equipped to evaluate the model in numerical simulations.

\subsection{Simulations}

The value for the common parameters, stochastic processes and functional forms are taken from the benchmark model. Different values of the parameters determining the output loss after default must be considered. Income is defined as

$\widetilde{y}(y, d, D)=I_{\phi<y}\left[I_{(D=1)}\left(I_{(d=0)} \phi \lambda_{g}+I_{(d=1)} \phi \lambda_{b}\right)+I_{(D=0)}\left(I_{(d=0)} y+I_{(d=1)} \phi \lambda_{p}\right)\right]+I_{\phi \geq y} y$.

The parameter $\phi$ has the same meaning and value that in the benchmark model. The parameters $\lambda_{b}, \lambda_{g}$, and $\lambda_{p}$ represent the punishment if both default, if only the government defaults, and if only the private sector defaults, respectively. We mantain $\lambda_{g}=1$ as in the benchmark calibration. To follow the concept of "sovereign credit ceiling" observed in the data, we set $\lambda_{p}$ slightly higher than $\lambda_{g} \cdot{ }^{13}$ Last, if both sectors default, we assume the punishment is harder, $\lambda_{b}=0.97$.

The results are presented in Table 6 . The main message is that private foreign borrowing does not modify the results in this paper. The first two columns present the correlations computed using directly the policy functions. For instance, $\rho(y, \tau)$ is

\footnotetext{
${ }^{12}$ Notice that $b^{\prime}\left(b_{0}, B_{0}, y\right)=b^{\prime}\left(b_{0}, B_{0}, y, \tau\left(b_{0}, B_{0}, y\right), B^{\prime}\left(b_{0}, B_{0}, y\right), D\left(b_{0}, B_{0}, y\right)\right)$. The same logic applies for $d$.

${ }^{13}$ This parameter is close enough to 1 , such that it does not imply a reward in case of default in the private sector for any income level in the grid.
} 
the correlation between $y$ and $\tau\left(b_{0}, B_{0}, y\right) \cdot{ }^{14}$ Since $b_{0}$ and $B_{0}$ are "free parameters" here, we present the results for low (first column) and high (second column) values of $b_{0}=B_{0}$. In the last column, the correlations were computed from time series simulated using the policy functions defined above. The results differ from the first columns because now $b$ and $B$ evolve over time according to $B^{\prime}(\cdot)$ and $b^{\prime}(\cdot)$. However, in all the exercises the government borrows more during booms and increases taxes during recessions. In the presence of a series of adverse shocks, the cost of rolling over debt and financing public expenditures increases and it becomes optimal to increase consumption taxes. Since the private sector may borrow somewhat from abroad, it might avoid an otherwise even more drastic fall in consumption, making it less costly to tax for the government. At the same time, since the cost of private borrowing also increases in recessions due to countercyclical credit risk, the private sector also faces procyclical borrowing and is constrained in bad times, so private debt is not a good instrument to smooth consumption.

\section{Conclusions}

In this paper we help rationalize the observed procyclicality of fiscal policy in emerging economies as the outcome of optimal public policy. Our paper contributes to the literature on fiscal policy and macroeconomic fluctuations in developing countries by analyzing the importance of incomplete markets and sovereign default risk premium in explaining the procyclicality of public expenditures and tax rates in these economies. The results are also consistent with other key stylized facts present in emerging market

\footnotetext{
${ }^{14}$ In computing those correlations, each point $y$ was weighted by the measure of $y$ in the stationary distribution of income.
} 
economies such as the countercyclicality of interest rate spreads and the procyclicality of borrowing.

We develop a dynamic stochastic model of a small open economy with endogenous fiscal policy and optimal sovereign default under incomplete credit markets. Since non-contingent debt is not a good instrument for consumption smoothing, public expenditures fluctuate. Although default incentives are stronger when output is lower, recessions do not always trigger such policy: a sovereign default typically occurs in a sufficiently large recession for a heavily indebted government. In that case the country is temporarily excluded from external credit markets and public expenditures are financed by taxation. When the economy faces a fall in output but the government does not default, it has the option to borrow from abroad but at a high interest rate. Since the cost of external credit increases in recessions, foreign debt financing of public expenditures becomes a relatively less attractive option compared to taxation. Therefore, complementing the previous literature that focused on the loss of market access, we find that the possibility of sovereign default and the associated risk premium play an important role in inducing the procyclical fiscal policy observed in emerging economies.

\section{Appendix}

\subsection{Algorithm for benchmark model}

From the first order condition of the household's problem and her budget constraint, we can get the following expressions for the optimal labor supply:

$$
l^{*}=\left[\frac{A}{1+T}\right]^{\frac{1}{\Psi}}
$$


this expression is plugged in 3.2 and 3.7, to get the following expressions for private consumption and public expenditures:

$$
\begin{aligned}
C^{*} & =\frac{A l^{*}}{(1+T)} \\
G & =T C^{*}+B-q\left(B^{\prime}, A\right) B^{\prime}
\end{aligned}
$$

which are plugged in 5.1:

$$
U\left(C^{*}, G, 1-l^{*}\right)=\frac{\left(C^{*}-\frac{\left(l^{*}\right)^{1+\Psi}}{1+\Psi}\right)^{1-\sigma}}{1-\sigma}+\frac{G^{1-\sigma}}{1-\sigma} .
$$

Assume an initial function for the price of the bond $q_{0}\left(B^{\prime}, A\right)$ as well as initial values for $V_{0}$ and $V^{d}$. To calculate the initial value of the bond, use the inverse of the risk free rate. For the initial values of the value functions, $\left(V_{0}\right)_{0}$ and $\left(V^{d}\right)_{0}$, start with 0 matrices, then the following algorithm is used:

1. Use $q_{0}$ to get $G_{0}$ from (9.1), then for every point ( $A, B$, and $B^{\prime}$ ) find the value of the tax rate, $T_{0}$, that maximizes (9.2).

2. Use $q_{0}$ and $T_{0}$ to express the per period utility (9.2) as a function of $B, B^{\prime}$, and $A$, then use $\left(V_{0}\right)_{0}$ and $\left(V^{d}\right)_{0}$ and equations (3.3), (3.8 ) and (3.9) to get $\left(V_{0}\right)_{1},\left(V^{d}\right)_{1}$, the policy function, $B^{\prime}(B, A)$ and default function $D(B, A)$ as well as the optimal tax rate associated with $A, B$ and $B^{\prime}(B, A)$.

3. Given the default function $D(B, A)$, and the repayment and default sets $\Gamma(\mathrm{B})$ and $\digamma(\mathrm{B})$, compute the probability of default $\lambda\left(B^{\prime}, A\right)$ using (3.11).

4. Update the price of the bond using the following equation:

$$
q_{1}=\frac{\left(1-\lambda\left(B^{\prime}, A\right)\right)}{1+r_{f}}
$$


5. Use the updated price of the bond $q_{1}$ and the value functions $\left(V_{0}\right)_{1}$ and $\left(V^{d}\right)_{1}$ to repeat steps 1, 2, 3 and 4 until the following conditions are satisfied:

$$
\begin{array}{r}
\max \left\{q_{0}\left(B^{\prime}, A\right)-q_{1}\left(B^{\prime}, A\right)\right\}<\epsilon \\
\max \left\{\left(V_{0}(B, A)\right)_{0}-\left(V_{0}(B, A)\right)_{1}\right\}<\epsilon \\
\max \left\{\left(V^{d}(A)\right)_{0}-\left(V^{d}(A)\right)_{1}\right\}<\epsilon
\end{array}
$$

where $\epsilon$ is a small number. 


\subsection{Tables and Figures}

\begin{tabular}{lcc}
\hline \hline \multicolumn{2}{c}{ Table 1. Parameter Values } \\
\hline Risk Aversion & $\sigma$ & 2 \\
Discount Factor & $\beta$ & 0.97 \\
Labor Elasticity & $\frac{1}{\Psi}$ & 2.22 \\
Re-entry Probability & $\mu$ & 0.10 \\
Default Penalty & $\phi$ & 0.99 \\
G Weight & $\pi$ & 0.30 \\
Risk Free Interest Rate & $r_{f}$ & 0.01 \\
Output Shock & $\rho$ & 0.85 \\
& $\sigma_{\epsilon}$ & 0.006 \\
\hline \hline
\end{tabular}

\begin{tabular}{lcc}
\hline \hline \multicolumn{3}{c}{ Table 2.} \\
\hline & $\begin{array}{c}\text { Mexican Data } \\
(1980-2007)\end{array}$ & $\begin{array}{c}\text { Benchmark } \\
\text { Model }\end{array}$ \\
\hline$\sigma(G D P)$ & 2.37 & 2.37 \\
$\sigma(C)$ & 2.90 & 2.44 \\
$\sigma($ Tax $)$ & 0.57 & 0.20 \\
$\sigma(T B / G D P)$ & 2.04 & 0.22 \\
$\rho(G D P, C)$ & 0.92 & 0.99 \\
$\rho(G D P, G)$ & 0.55 & 0.97 \\
$\rho(G D P, T a x)$ & -0.33 & -0.35 \\
$\rho(G D P$, Spread $)$ & -0.63 & -0.29 \\
$\rho(G D P$, TB $/$ GDP $)$ & -0.72 & -0.36 \\
\hline \hline
\end{tabular}




\begin{tabular}{lccc}
\hline \hline & Table 3. Simulation Results & \\
& Benchmark & Model & Model \\
& Model & Without Default & With Labor tax \\
\hline$\sigma(G D P)$ & 2.37 & 2.37 & 2.37 \\
$\sigma(C)$ & 2.44 & 2.23 & 2.43 \\
$\sigma($ Tax $)$ & 0.20 & 0.18 & 0.18 \\
$\rho(G D P, C)$ & 0.99 & 0.99 & 0.99 \\
$\rho(G D P, G)$ & 0.97 & 0.97 & 0.97 \\
$\rho(G D P, T a x)$ & -0.35 & 0.63 & -0.34 \\
$\rho(G D P, T B / G D P)$ & -0.36 & 0.61 & -0.35 \\
\hline \hline
\end{tabular}

Table 4 .

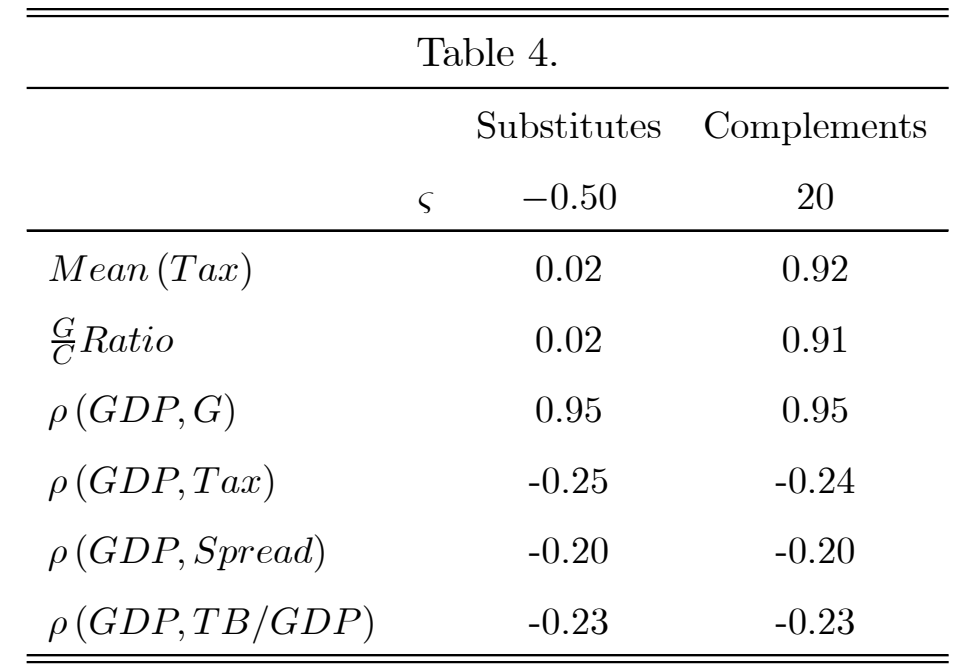




\begin{tabular}{l}
\hline $\begin{array}{r}\text { Table 5. Public and private foreign } \\
\text { debt in developing countries }\end{array}$ \\
\hline Private sector debt accounting for less than $10 \%$ of total \\
external debt.
\end{tabular}

Source: Reinhart, Rogoff and Savastano (2003).

\begin{tabular}{lccc}
\hline \hline \multicolumn{2}{c}{ Table 6. The economy with private foreign borrowing } \\
\hline & \multicolumn{2}{c}{ Initial debt } & Time \\
Correlations & Low & High & Series \\
\hline$\rho(y, \tau)$ & -0.238 & -0.937 & -0.864 \\
$\rho\left(y, q_{p} b_{1}\right)$ & -0.863 & -0.823 & -0.716 \\
$\rho\left(y, q_{g} B_{1}\right)$ & -0.189 & -0.927 & -0.207 \\
$\rho\left(y, C_{1}\right)$ & 0.990 & 0.994 & 0.971 \\
$\rho\left(y, G_{1}\right)$ & 0.990 & 0.994 & 0.971 \\
\hline \hline
\end{tabular}

Note: the correlations in this table are comparable among them but not with those in Tables 2,3 , and 4 , because the data was not filtered. By construction, filtering does not make sense in column 2 and 3. 
Figure 1 Bond Price

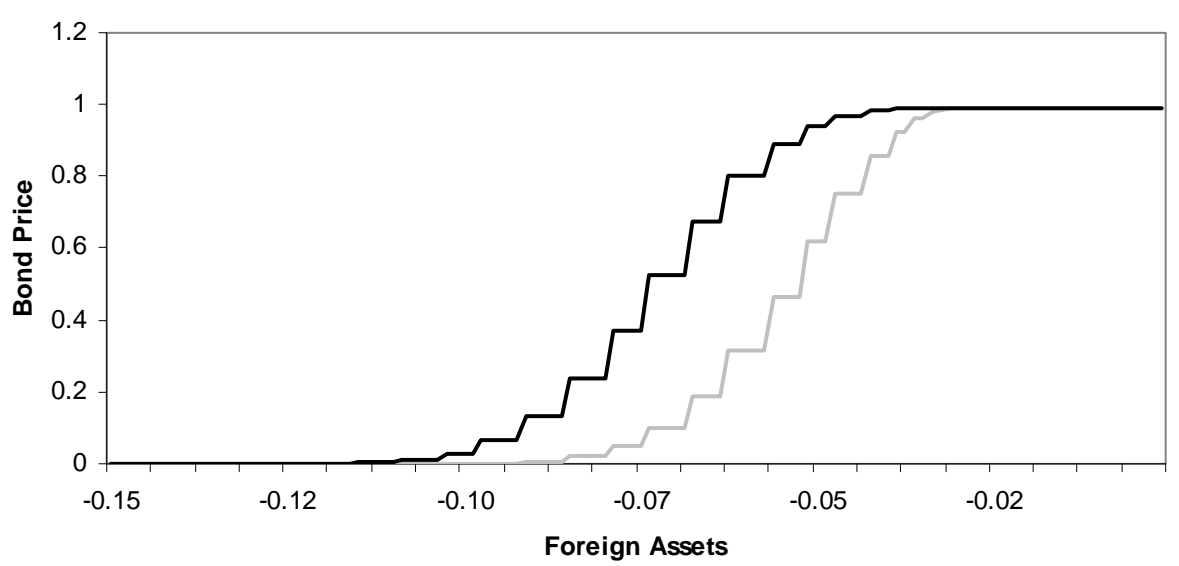

_Low Shock __High Shcock 
Figure 2 Dynamics of GDP and Spread

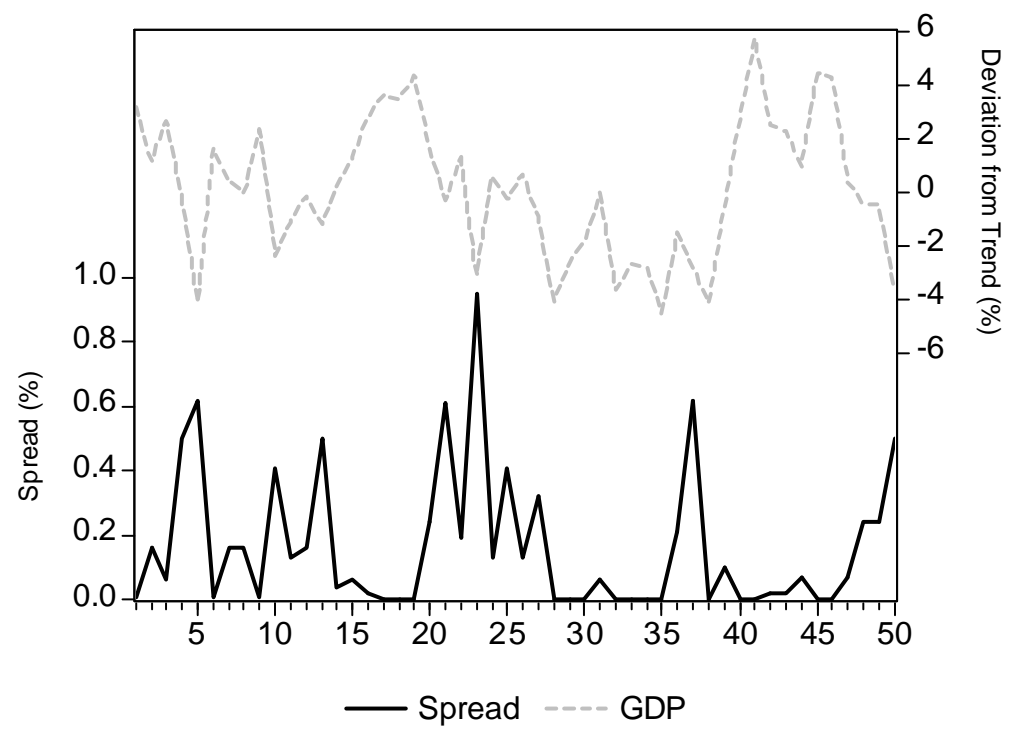

Figure 3 Dynamics of GDP and Tax Rate

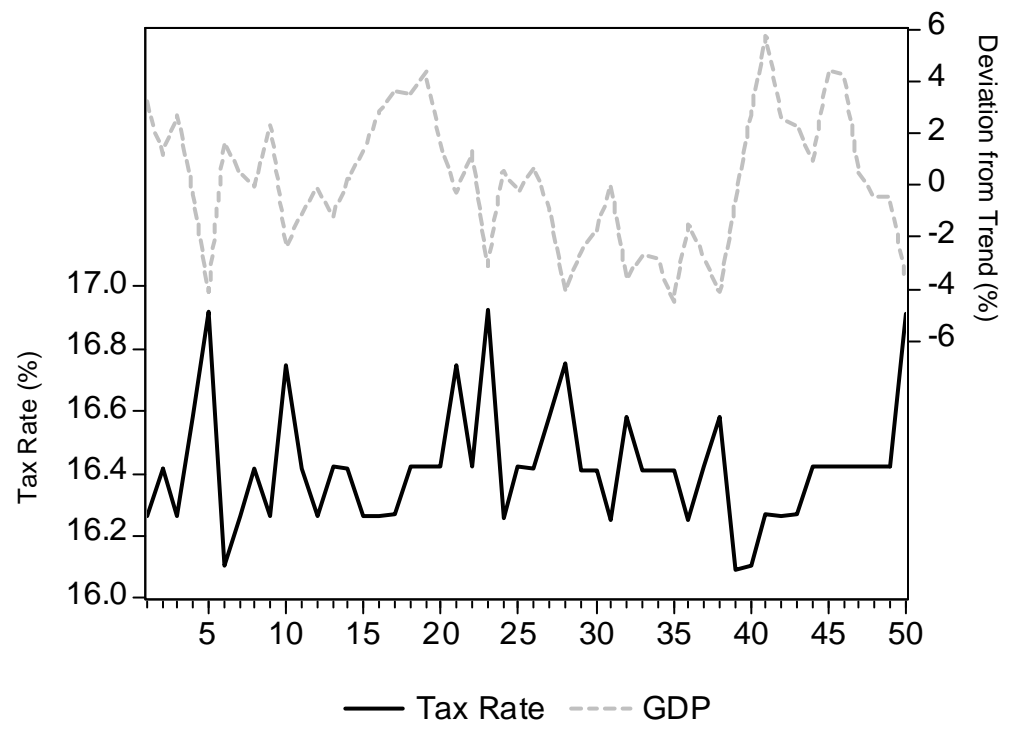


Figure 4 Tax Rate Policy T(B,A)

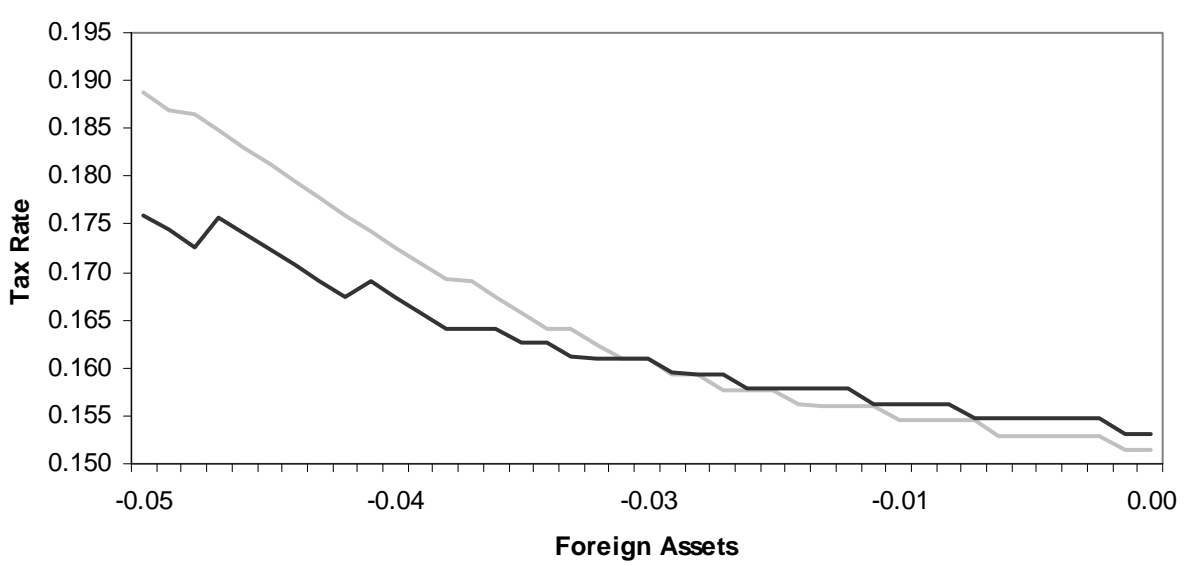

__ Low Shock __High Shock

Figure 5 Borrowing Function $B^{\prime}(B, A)$

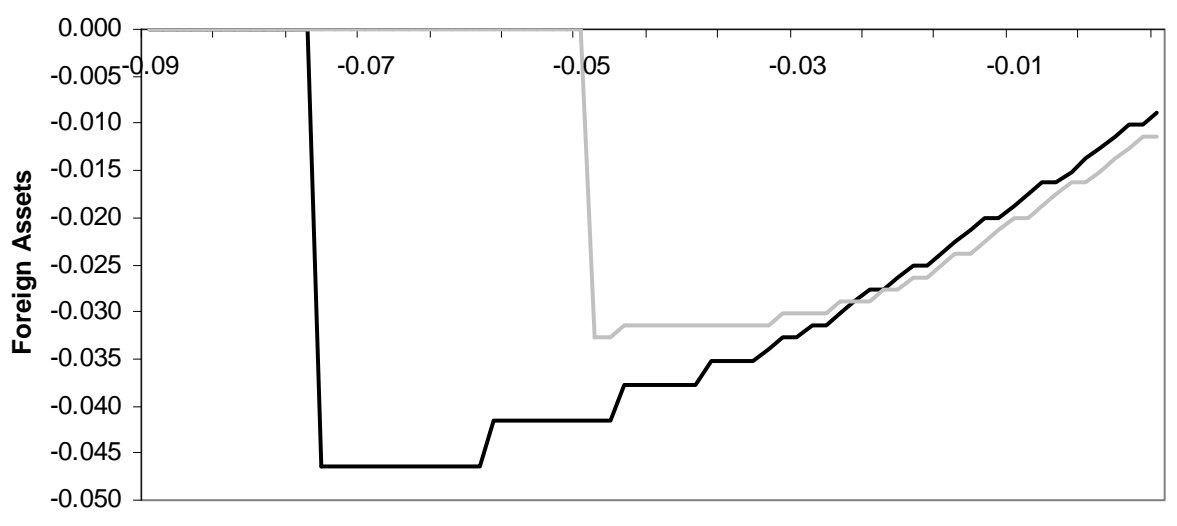

Foreign Assets

—High Shock —_Low Shock 


\section{References}

[1] Aguiar, M. and G. Gopinath, 2006. Defaultable Debt, Interest Rates and the Current Account, Journal of International Economics 69, 64-83.

[2] Aguiar, M and G. Gopinath 2007. Emerging Markets Business Cycle: The Cycle is the Trend, Journal of Political Economy 115, 69-102.

[3] Aizenman, J., M. Gavin and R.Hausmann 2000. Optimal Tax and Debt Policy with Endogenously Imperfect Creditworthiness, Journal of International trade \& Economic Development 9/4, 367-395.

[4] Alesina A. and G. Tabellini, 2008. Why is Fiscal Policy Often Procyclical?, Journal of the European Economic Association, 6(5), 1006-1036, 09.

[5] Arrow, K.J. and R.C.Lind, 1970, Uncertainty and the evaluation of public investment decisions, American Economic Review, 60, 364-78.

[6] Arellano, Cristina, 2008. Default Risk and Income Fluctuations in Emerging Economies, American Economic Review 98(3), 690-712.

[7] Arteta C. and G. Hale, 2006. Sovereign Debt Crises and Credit to the Private Sector, Journal of International Economics, 74(1), pages 53-69.

[8] Barro, Robert J., 1979. On the Determination of Public Debt, Journal of Political Economy, 87, 940-971.

[9] Borensztein, E., K. Cowan, and P. Valenzuela, 2006, The Sovereign Credit Ceiling Lite. Inter-American Development Bank and Central Bank of Chile, mimeo. 
[10] Cantor, R. and F. Packer, 1996. Determinants and Impact of Sovereign Credit Ratings, Economic Policy Review, Federal Reserve Bank of New York.

[11] CEPAL, 2008. Estudio Economico de America Latina y el Caribe, 2007-2008, Chapter IV.

[12] Claessens, Stijn, 2006. Access to Financial Services: A Review of the Issues and Public Policy Objectives, World Bank Research Observer 21(2): 207-240.

[13] Chatterjee, S., D. Corbae, M. Nakajima and V. Rios-Rull, 2007. A Quantitative Theory of Unsecured Consumer Credit with Risk of Default, Econometrica, 75(6), $1525-1589$.

[14] Copelman, Martina, 1996. The Role of Credit in Post-Stabilization Consumption Booms, Board of Governors of the Federal reserve System, International Finance Discussion Paper No 569.

[15] Cuadra G. and H. Sapriza, 2008. Sovereign Default, Interest Rates and Political Uncertainty in Emerging Markets, Journal of International Economics 76, 78-88.

[16] Dooley, Michael, 2000. International Financial Architecture and Strategic Default: Can Financial Crises Be Less Painful?, Carnegie-Rochester Conference on Public Policy 53, 361-377.

[17] Durbin, E. and D. Ng, 2005, The sovereign ceiling and emerging market corporate bond spreads, Journal of International Money and Finance 24, 631-649.

[18] Eaton, J. and M. Gerzovitz,1981. Debt with Potential Repudiation: Theoretical and Empirical Analysis, Review of Economic Studies 48, 289-309. 
[19] Erosa, A. and G. Ventura, 2001. On Inflation as a Regressive Consumption Tax, Journal of Monetary Economics 49(4), 761-795.

[20] Gavin, M. and R. Perotti, 1997. Fiscal Policy in Latin America, NBER Macroeconomics Annual, 11-61.

[21] Gelos, G., R. Sahay and G. Sandleris, 2003. Sovereign Borrowing by Developing Countries: What Determines Market Access?, Working Paper, IMF.

[22] Hatchondo J., L. Martinez and H. Sapriza, 2008. Heterogeneous Borrowers in Quantitative Models of Sovereign Default, International Economic Review, forthcoming.

[23] Huggett, Mark, 1993. The Risk Free Rate in Heterogenous Agents Incomplete Insurance Economies, Journal of Economic Dynamics and Control 17, 953-969.

[24] Hussey, R., and G. Tauchen, 1991. Quadrature-Based Methods for Obtaining Approximate Solutions to Nonlinear Asset Pricing Models, Econometrica 59, 371-396.

[25] Ilzetzki E. and C. Vegh, 2008. Procyclical Fiscal Policy in Developing Countries: Truth or Fiction?, NBER Working Paper 14191.

[26] Lahiri, A., Singh, R., Vegh, C., 2007. Segmented asset markets and optimal exchange rate regimes, Journal of International Economics 71 (1), 1-21.

[27] Lane, P. and A. Tornell, 1999. The Voracity Effect, American Economic Review $89,22-46$.

[28] IMF Financial Stability Report, 2007.

[29] Lizarazo, Sandra, 2006. Default Risk and Risk Adverse International Investors, Working Paper, ITAM. 
[30] Mailhos J. and S. Sosa, 2000. On the Procyclicality of Fiscal Policy: The Case of Uruguay, CERES Working Paper.

[31] Mendoza, Enrique, 1991. Real Business Cycles in a Small Open Economy, American Economic Review 81, 797-818.

[32] Mendoza, E., A. Razin and L. Tesar, 1994. Effective Tax Rates in Macroeconomics: Cross-Country Estimates of Tax Rates on Factor Incomes and Consumption. NBER Working Paper 4864.

[33] Neumeyer, P. and F. Perri, 2005. Business Cycles in Emerging Economies: The Role of Interest Rates, Journal of Monetary Economics 52/2, 345-380.

[34] Kaminsky, G., C. Reinhart and C. Vegh, 2004. When It Rains, It Pours: Procyclical Capital Flows and Macroeconomic Policies, NBER Macroeconomics Annual 2004.

[35] Peter, Marcel, 2002. Estimating Default Probabilities of Emerging Market Sovereigns: A new Look at a Not-So-New Literature, Working Paper, The Graduate Institute of International Studies, Geneva.

[36] Reinhart, C., K. Rogoff and M. Savastano, 2003. Debt Intolerance, NBER Working Paper 9908.

[37] Reinhart, Rogoff and Savastano, 2003. Addicted to dollars, NBER WP 10015.

[38] Riascos, A. and C. Vegh, 2003. Procyclical Government Spending in Developing Countries: The Role of Capital Market Imperfections, Working Paper, UCLA.

[39] Rose, Andrew, 2005. One Reason Countries Pay Their Debts: Renegotiation and International Trade, Journal of Development Economics 77, 189-206. 
[40] Uribe, Martín, 2006. Lectures in Open Economy Macroeconomics, Duke University.

[41] Uribe, Martin and Schmitt-Grohe, 2003. Closing Small Open Economy Models, Journal of International Economics 61, 163-185.

[42] Uribe, M. and V.Yue, 2006. Country Spreads and Emerging Countries: Who Drives Whom?, Journal of International Economics 69, 6-36.

[43] Talvi, E. and C. Vegh, 2005. Tax Base Variability and Procyclical Fiscal Policy, Journal of Development Economics 78, 156- 190.

[44] Vicente, L. and I. Rial, 2007. Política Fiscal y Vulnerabilidad Fiscal en Uruguay, 1976-2006, Central Bank of Uruguay and IMF, mimeo.

[45] Yue, Vivian, 2007. Sovereign Default and debt renegotiation, Working Paper, New York University. 